\title{
VERSITA
}

\section{URBAN ECOSYSTEM SERVICES ON THE LOCAL LEVEL: URBAN GREEN SPACES AS PROVIDERS}

\author{
JÜRGEN BREUSTE ${ }^{1}$, JOHANNA SCHNELLINGER ${ }^{1}$, SALMAN QURESHI² ANNA \\ FAGGI $^{3}$
}

\begin{abstract}
${ }^{1}$ Research Group for Urban and Landscape Ecology, Department of Geography and Geology, University of Salzburg, Hellbrunnerstrasse 34, Salzburg 5020, Austria; e-mail: juergen.breuste@sbg.ac.at, Johanna Schnellinger@anl. bayern.de

${ }^{2}$ School of Architecture, Birmingham City University, Gosta Green, Birmingham B4 7DX, UK Institute of Geography, Humboldt University of Berlin, Rudower Chaussee 16, D-12489 Berlin, Germany; e-mail: salloo19yahoo.com ${ }_{3}^{3}$ Museo Argentino de Ciencias Naturales, Dto. Botánica, Ecología Regional. Conicet, Angel Gallardo 470, 2 do piso. Buenos Aires, (1405), Argentina; e-mail: afaggiio@macn.gov.ar
\end{abstract}

Abstract

Breuste J., Schnellinger J., Qureshi S., Faggi A.: Urban ecosystem services on the local level: Urban green spaces as providers. Ekológia (Bratislava), Vol. 32, No. 3, p. 209-304, 2013.

Ecosystem services are provided at different spatial and service/functional scales. The local level is the basic unit for ecosystem services, especially when it comes to the human dimension of urban landscapes. These services are provided by green elements (patches) or basic complex ecosystems (green areas) which differ from their neighbourhoods through their structures and functions. This study reviews the generally available knowledge on urban green functions and services at the site level and explains them by using own studies in five different cities in three different continents related to distinct ecosystem services. This allows the development of a methodology to evaluate and compare ecosystem services at the site level. The methodology is based at two levels, patch and green space, and includes the relationship with the surrounding green and built-up space. Different urban green space types are characterized by their internal structures of vegetation, size, shape and location in relation to at least a semi-quantitative scaling of their urban ecosystem services. The evaluated urban green spaces are public urban green spaces. The urban ecosystem services assessed include climate regulation, biodiversity, nature experience, recreation and health. The actual urban challenges, such as land use change, adaptation to climate change, demographic change and urban cultural diversity, demand a systematic and very concrete monitoring of urban ecosystem services at the site level.

Key words: biodiversity, ecosystem services, habitat provision, nature experience, urban indicators, recreation, urban parks.

\section{Introduction}

The Millennium Ecosystem Assessment (2003) describes ecosystem services as benefits that people obtain from ecosystem. These include provisioning services such as food and water; regulating services such as regulation of floods, drought, land degradation and disease; supporting services such as soil formation and nutrient cycling; and cultural services such as recreational, spiritual, religious and other non-material benefits. The concept of ecosystem services helps to place value on ecological functions, often to the direct benefit of human 
populations in terms of physical health, or in economic or social terms (Ahern, 2007). Costanza et al. (1997) identified 17 major categories of services provided by varying types of ecosystems. Urban green is referred to as the major ecosystem services provider in urban landscapes for majority of the people (Tratalos et al., 2007). In reality, only small parts (specific ecosystems) of them provide these services. The specific site-related ecosystem services are provided by urban green - the main provider of urban ecosystem services. It needs to be evaluated quantitatively and included in urban design and planning. However, there have been a few empirical investigations into its site-based relevance to human health and social well-being, and thus considered to be investigated urgently (Qureshi et al., 2010b).

\section{Ecosystem services at site level}

\section{Urban green}

Urban green, as the main provider of ecosystem services, in cities consists of different green elements (patches), e.g. single trees in streets and gardens, tree covers of different layers, lawns and grass, bushes and shrubs, flower beds and ornamental plant arrangements etc., in different ownership. These 'basic units' are parts of multi-structural green areas, e.g. green corridors that follow transportation networks, parks and gardens, natural wild spaces, urban forest and community woodlands, cemeteries, allotments, playing fields and playgrounds, derelict and despoiled vacant land, or, to a lesser extent, of built-up urban structural units.

Many people can benefit from ecosystem services in public green spaces because of their accessibility. However, quantitatively residential areas are the biggest ecosystem service provider with their larger green areas. Loram et al. (2007) studied five British cities and concludes that private domestic gardens covered between 21.8 and $26.8 \%$ of the whole urban area. Large differences in tree and shrub cover distinguish the urban structural units from each other (e.g. Pauleit, Duhme, 2000; Gill et al., 2007). The tree and shrub cover ranges from a minimum of $4 \%$ to a maximum of $55 \%$ for the US cities (Nowak et al., 1996).

The green patches of open spaces within urban areas range from vegetation remnants of the original natural landscape (mainly woods and wetlands), vegetation of the agricultural cultural landscapes (e.g. meadows and arable land), ornamental, horticultural and designed urban vegetation spaces (parks and gardens) to spontaneous urban vegetation (brownfields and derelict land). These four main groups of vegetation cover are results of different land uses and intensities of utilization and maintenance. They fulfil different ecosystem services and provide potential for even more (Pauleit, Breuste, 2011; Breuste et al., 2013a, b) (Table 1).

\section{Ecosystem services in urban landscapes}

Bolund and Hunhammar (1999) named six ecosystem services relevant for their investigations in Stockholm: air filtering, microclimate regulation, noise reduction, rainwater drainage, sewage treatment and recreation/cultural values. Water supply, landscape (aesthetical value), sense of identity and provision of land for economic and commercial activities and housing can be added. They also combine the ecosystem services with quality of life indicators (Table 2). 
T a b l e 1. Ecosystem services of urban green. Breuste according to Arbeitsgruppe Methodik der Biotopkartierung im besiedelten Bereich • (1993); Kowarik, 1992; Bolund, Hunhammar, 1999 (modified).

\begin{tabular}{|c|c|c|c|}
\hline Vegetation group & Vegetation structure type & $\begin{array}{l}\text { Main existing ecosystem } \\
\text { services }\end{array}$ & $\begin{array}{l}\text { Main potential } \\
\text { ecosystem services }\end{array}$ \\
\hline $\begin{array}{l}\text { (A) Vegetation rem- } \\
\text { nants of the original } \\
\text { natural landscape }\end{array}$ & $\begin{array}{l}\text { Woods and forests } \\
\text { Wetlands }\end{array}$ & $\begin{array}{l}\text { Timber production, recrea- } \\
\text { tion, biodiversity, microclimate } \\
\text { regulation, rainwater drainage, } \\
\text { sewage treatment }\end{array}$ & Nature experience \\
\hline $\begin{array}{l}\text { (B) Vegetation of the } \\
\text { cultural landscapes } \\
\text { formed by agriculture }\end{array}$ & $\begin{array}{l}\text { Meadows, pastures, } \\
\text { drifts, dry grasslands, } \\
\text { arable land }\end{array}$ & $\begin{array}{l}\text { Food production, } \text { microcli- } \\
\text { mate regulation, rainwater } \\
\text { drainage }\end{array}$ & $\begin{array}{l}\text { Recreation, biodiver- } \\
\text { sity, nature experience }\end{array}$ \\
\hline \multirow[t]{4}{*}{$\begin{array}{l}\text { (C) Ornamental, hor- } \\
\text { ticultural and designed } \\
\text { urban vegetation spaces }\end{array}$} & $\begin{array}{l}\text { Decorative green (flower } \\
\text { beds, small lawn patches, } \\
\text { bushes, hedges etc.) }\end{array}$ & Decoration, cultural values & $\begin{array}{l}\text { Biodiversity, rainwater } \\
\text { drainage }\end{array}$ \\
\hline & $\begin{array}{l}\text { Accompanied green along } \\
\text { traffic lines or as addition } \\
\text { to fill up the space between } \\
\text { apartment blocks }\end{array}$ & $\begin{array}{l}\text { Air filtering, microclimate reg- } \\
\text { ulation, rainwater drainage }\end{array}$ & $\begin{array}{l}\text { Recreation, biodiver- } \\
\text { sity }\end{array}$ \\
\hline & $\begin{array}{l}\text { Gardens/parks } \\
\text { Allotment gardens Urban } \\
\text { trees }\end{array}$ & & \\
\hline & & $\begin{array}{l}\text { Recreation, microclimate regu- } \\
\text { lation, air filtering, }\end{array}$ & $\begin{array}{l}\text { Biodiversity, nature } \\
\text { experience, learning } \\
\text { about nature }\end{array}$ \\
\hline $\begin{array}{l}\text { (D) Spontaneous urban } \\
\text { vegetation spaces }\end{array}$ & $\begin{array}{l}\text { Spontaneous herbaceous } \\
\text { bush and pre-forest vegeta- } \\
\text { tion }\end{array}$ & $\begin{array}{l}\text { Biodiversity, } \\
\text { regulation }\end{array}$ & $\begin{array}{l}\text { Biodiversity, learning } \\
\text { about nature, nature } \\
\text { experience, } \\
\text { recreation }\end{array}$ \\
\hline
\end{tabular}

$\mathrm{T} \mathrm{a} \mathrm{b} \mathrm{l} \mathrm{e} \mathrm{2.} \mathrm{Services} \mathrm{and} \mathrm{indicators} \mathrm{of} \mathrm{quality} \mathrm{of} \mathrm{life} \mathrm{related} \mathrm{to} \mathrm{the} \mathrm{dimensions} \mathrm{of} \mathrm{sustainability} \mathrm{(changed} \mathrm{after} \mathrm{Breuste}$ et al., 2011; according to Millennium Ecosystem Assessment, 2005 and Santos, Martins, 2007).

\begin{tabular}{lll}
\hline Sustainability dimension & Urban ecosystem service & Quality of life indicator \\
\hline Ecology & Air filtration & Health (clean air, protection against \\
& Climate regulation & respiratory diseases, protection \\
& Noise reduction & against heat and cold death) \\
& Rainwater drainage & Safety \\
& Water supply & Drinking water \\
& Wastewater treatment & Food \\
Food production & \\
Lacial sphere & Landscape & Beauty of the environment \\
& Recreation & Recreation and stress reduction \\
& Cultural values & Intellectual endowment \\
& Sense of identity & Communication \\
& Health & Place to live \\
Economy & Provision of land for economic and & Accessibility \\
& commercial activities and housing & Income \\
\hline
\end{tabular}


Following the guidelines of the Millennium Ecosystem Assessment (2005), Costanza et al. (1997) classifies urban ecosystem services into four broad categories:

- Provisioning services (food, timber, water supply, provision of genetic resources and biodiversity).

- Regulating services (regulation of climate extremes such as heavy rainfall and heat waves, floods, diseases, regulation of water flows, treatment and handling of waste).

- Cultural services (recreation, provision of aesthetic features, spiritual requirements, nature experience, and education).

- $\quad$ Supporting services (soil formation and processes, pollination or energy, matter, nutrient fluxes).

Out of these, biodiversity, climate regulation, recreation and nature experience are of main significance for urban health and well-being.

\section{Methodology - evaluation of ecosystem services in four cities}

Four case studies, each related to a different ecosystem service, have been selected to quantify ecosystem services at the site level. The case studies are original research studies of the authors or were supervised by them (Czermak, 2008; Stern, 2010; Qureshi et al., 2010a, b, (Breuste et al., 2013a, b) through project work. They are located in different cities of different sizes in three continents. The selected ecosystem services are as follows:

- Climate regulation

- Biodiversity

- $\quad$ Nature experience

- Recreation

\section{Climate regulation}

Karachi metropolitan area has experienced a tremendous population growth (currently having about 18 million inhabitants) and urban sprawl $\left(3,527 \mathrm{~km}^{2}\right)$, resulting not only in long commuting distances for urban dwellers but also in an increased burden on natural resources (Qureshi, 2010). The vegetation cover of the natural resources is being replaced largely by built-up land for residential and commercial purposes (Qureshi et al., 2010b). There is thus a dire need to monitor these changes in vegetation and built-up cover and compare this with the measured thermal conditions.

In this study satellite images were used to derive the land-use and land-cover (LULC) changes of Karachi. A time series of Landsat TM images were used for the years 1986-2003. Multi-temporal images were processed for radiometric and geometric errors to evaluate the LULC changes. This helped identify the major areas of changes at local level. Furthermore, this method helped to identify the neighbourhoods (local level) of very unique character. Therein the green spaces had been surveyed to observe the possible relationships between different land uses and microclimatic conditions (thermal comfort in this case).

Concurrently, a trend analysis of the mean annual temperature (MAT) was conducted of air temperature data for the time series of the years 1961-2009. The average of five different locations in Karachi was provided and used in this study (Breuste et al., 2013a, b).

\section{Biodiversity}

In a study in Linz, Austria (190,000 inhabitants), all 19 public parks larger than 1 ha were investigated for their biodiversity service on the basis of breeding birds as indicators, documented in the Breeding Bird Atlas of Linz (Weissmair et al., 2000-2001). Birds are good biodiversity indicators and react very sensitively to different environmental qualities. For Linz, 122 different species of birds were listed; 102 of them could be counted as breeding birds. Twenty species were classified as non-breeding (passing and food seeking).

The bird species number marks the observed bird in the areas. The breeding status of the green space can be defined with three breeding categories: BS $1=$ Breeding possible, BS $2=$ Breeding probable and BS $3=$ Breeding 
proven. Every observed species is given a breeding status. The summary of the three breeding category numbers per species gives a quantification of the bird breeding importance of the park. BS 1 15, for example, means 15 breeding species possible. Species numbers in category BS 3 are multiplied with a factor of 3 , in category BS 2 with a factor of 2 to weight proved breeding and probable breeding more than the possible breeding status. The summary of the three breeding statuses provides a breeding number (Breuste et al., 2013b).

\section{Nature experience}

One of the most dynamic urban green developments worldwide is occurring in Shanghai (China). Between 1978 and 2006 the city extended its green area from 761 to 30,609 ha. The area of public parks increased during this time from 309 ha to 1529 ha. For the majority of the urban dwellers the public parks are the only possibility for any contact and experiences with nature. They are essential for this ecosystem function.

In a study in Changning district of Shanghai (China) (614,200 inhabitants, 2006) the nature experience function of three public parks was investigated by Stern (2010). In the three public parks - Zhongshan, Kai Qiao and Tianshan - the function of nature experience was investigated by 322 interviews of visitors of all age groups (Zhongshan park 118, Kai Qiao park 103 and Tianshan park 101) (Stern, 2010; Breuste et al., 2013a).

\section{Recreation}

In a study in Buenos Aires, Argentina, five urban parks were investigated to evaluate the recreational function of the areas. Five hundred visitors were questioned about their recreational behaviour to qualify and quantify the recreational function of the green spaces. The parks Parque Micaela Bastidas, Parque Presidente Nicolas Avellaneda, Parque General Las Heras, Parque Brigadier Cornelio de Saavedra, Parque del Centenario are typical neighbourhood parks of medium size (4-10 ha) in the central district of Buenos Aires in a middle class areas. They are established with lawns, trees, bushes and playgrounds. Excluding Parque Micaela Bastidas, all parks are located in highly populated areas (14.000-16.000 inhabitants $/ \mathrm{km}^{2}$ ) with high recreation demand (Breuste et al. 2013b).

\section{Results}

\section{Climate regulation - Karachi, Pakistan, study}

Ther urban green of the city Karachi is decling (Qureshi et al., 2010b) (Fig. 1). Between 1986 and 2003 the built-up land has increased from 104 to $200 \mathrm{~km}^{2}$, whereas the overall green cover has been reduced from 111 to $75 \mathrm{~km}^{2}$. Furthermore, urban development has taken over more than $50 \mathrm{~km}^{2}$ of the open spaces in and around Karachi. However, the temperature trend suggests that the temperature has increased up to $4^{\circ} \mathrm{C}$ in Karachi.

The areas which are densely populated suppress the cooling effect of the green space due to increased concrete structures. The smaller green spaces are surrounded by walls from the neighbouring built-up areas (Fig. 1), which reduces the ability of parks to provide temperature moderation. Parks have to be of a certain size to provide a comfortable microclimate. However, some larger green spaces, also due to their regional functional character, maintain their position as providers of microclimate services at a local scale (Breuste et al., 2013a).

\section{Biodiversity - Linz, Austria, study}

The very best park in the evaluation (Bauernberg Park) has 37 species and a breeding number of 71 . The park has an area of 9.54 ha and is richly structured by different vegetation types, especially old trees and small forest patches. The park with the worst result in the evaluation (Harbach Park 1.39 ha) has only 1 species and a breeding number of 2. 

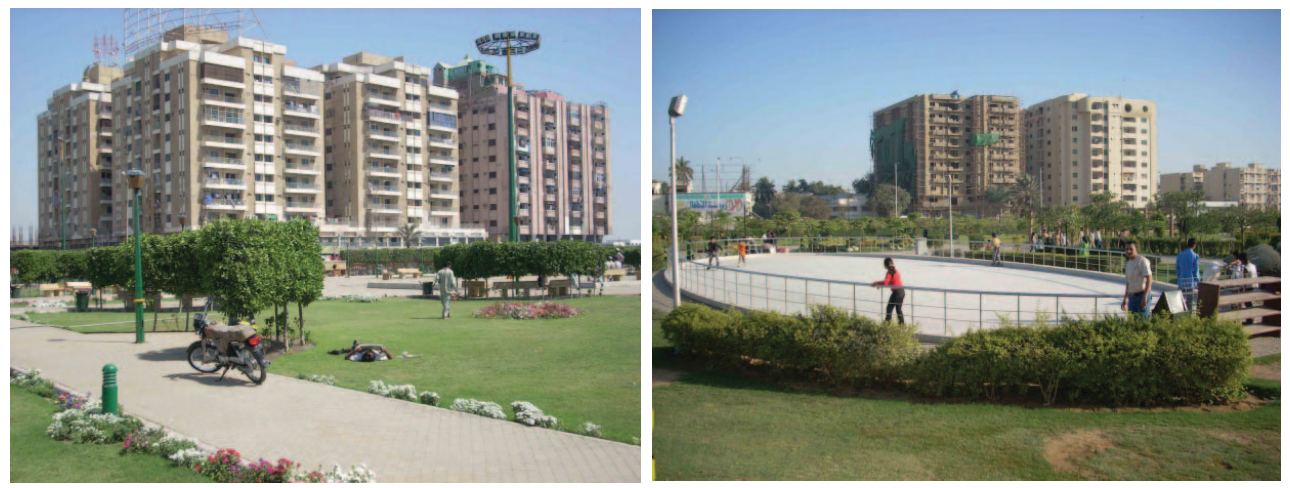

Fig. 1. Green spaces in Karachi surrounded by high rise residential buildings. (Left - Beach View Park; Right Askari Park).

The difference in size and structure, together with a comparable utilization level, expresses a clear difference in disturbance, a very important factor for ecological functionality. This can be better expressed by, for instance, birds (or other animals) than only by vegetation types. In this sense, birds are more sensitive indicators for biodiversity than for vegetation.

The study also shows big differences between the parks which could not be expected just because of the green area structure. It also shows that biodiversity very much depends on size (and shape), disturbance and intensity of utilization of the parks. The different breeding categories (Table 3) are unevenly distributed in the parks. Especially the category 'breeding possible' (BS 1) shows much biodiversity potential to improve the biodiversity service, even for parks of only middle rank.

An additional preliminary study on the realization of biodiversity by the visitors shows no significant difference between the Bauernberg Park and the Harbach Park (Czermak, 2008). This links to the hypotheses that biodiversity is not always recognized by visitors without experience. Another interpretation is that the valuation of nature experience functions depends very much on the available and practical (nearest park) possibilities. The results of the Linz study also show that the highest number of bird species in the urban region can be found in unsettled areas in flood plains (70) and forests (77) and are very low in agricultural areas (52-52). In urban areas the highest numbers of bird species can be found in urban green spaces (65) and detached house neighbourhoods (villa areas) (63), much more than in any other residential areas (54) (Czermak, 2008; Breuste et al., 2013 b).

\section{Nature experience and education - Shanghai, China, study}

All parks investigated in Shanghai are very intensively used on all days from morning to evening. This shows the great relevance of parks in Shanghai's urban life for the close neighbourhood population, where most of the visitors come from; the environmental conditions being the important reasons for visiting (83-94\%) (Fig. 2).

The term 'environmental conditions' describes the visitor's perspective on the natural features of the parks as different surroundings compared to the limited spaces and nature in 
T a b l e 3. Biodiversity classifications of the Linz urban parks by breeding bird species. Source: Czermak, 2008, p. 57 and 63, changed.

\begin{tabular}{|l|l|l|l|l|l|}
\hline Parks & BS 1 & BS 2 & BS 3 & $\begin{array}{l}\text { Aggregate value } \\
\text { of different bree- } \\
\text { ding categories }\end{array}$ & $\begin{array}{l}\text { Number of bree- } \\
\text { ding bird species }\end{array}$ \\
\hline Bauernberg & $\mathbf{1 5}$ & $\mathbf{1 0}$ & $\mathbf{1 2}$ & $\mathbf{7 1}$ & $\mathbf{3 7}$ \\
\hline Freinberg West-Ost & 12 & 12 & 8 & 52 & 32 \\
\hline Hummelhofwald & 10 & 8 & 13 & 65 & 31 \\
\hline Freinberg Aroboretum & 9 & 8 & 8 & 51 & 24 \\
\hline Bergschlüsl & 1 & 14 & 9 & 37 & 25 \\
\hline Panuliwiese & 11 & 6 & 7 & 37 & 24 \\
\hline Wasserwald & 10 & 10 & 3 & 36 & 22 \\
\hline Schlossberg & 3 & 10 & 9 & 41 & 23 \\
\hline Donaupark & 6 & 13 & 2 & 36 & 21 \\
\hline Volksgarten & 6 & 7 & 6 & 32 & 19 \\
\hline Universitäspark & 6 & 6 & 4 & 26 & 16 \\
\hline Pütlingsberg & 6 & 6 & 3 & 24 & 15 \\
\hline J.W.Kleinstrasse & 4 & 5 & 1 & 16 & 10 \\
\hline Wag-Park & 4 & 5 & 1 & 16 & 10 \\
\hline Ökopark & 7 & 1 & 2 & 13 & 10 \\
\hline Ing.Stern.Strasse & 2 & 2 & 5 & 16 & 9 \\
\hline Erholungspark Urfahr & 3 & 1 & 3 & 11 & 7 \\
\hline Peuerbachstrasse & 3 & 1 & 0 & 5 & $\mathbf{1}$ \\
\hline Harbachpark & $\mathbf{0}$ & $\mathbf{0}$ & $\mathbf{1}$ & $\mathbf{2}$ & 4 \\
\hline
\end{tabular}

Notes: BS 1 = Breeding possible, BS 2 = Breeding probable and BS 3 = Breeding proved.
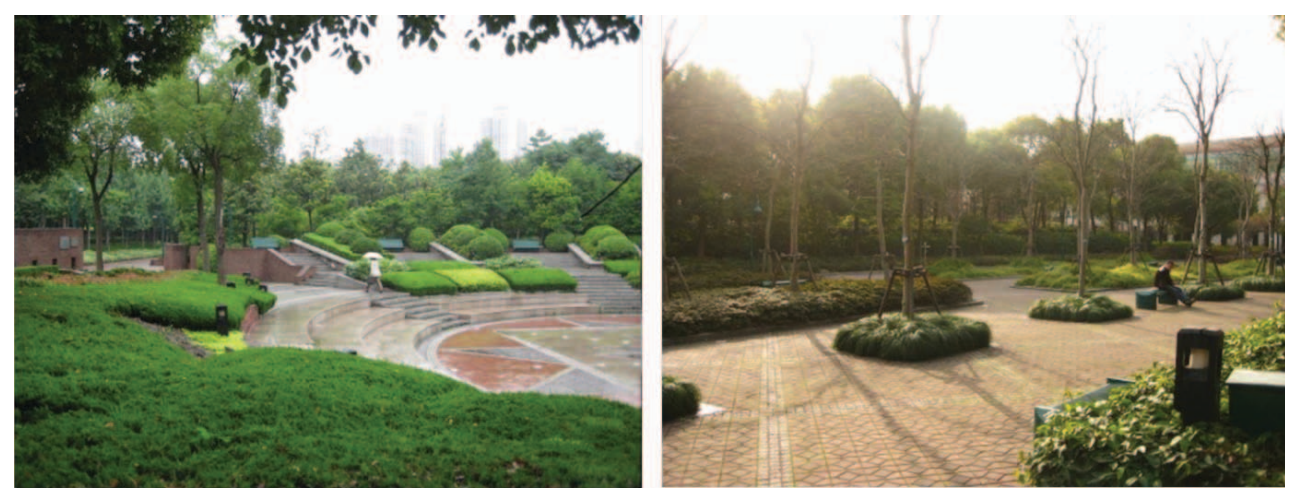

Fig. 2. Park nature in Kai Qiao Park, Shanghai (Photo: N. Stern).

Shanghai's residential areas. The majority of visitors questioned also expressed the view that nature experience is an important reason for visiting the park (73-86\%). The ornamental nature of the parks creates the general vision of nature for most of the urban dwellers. 


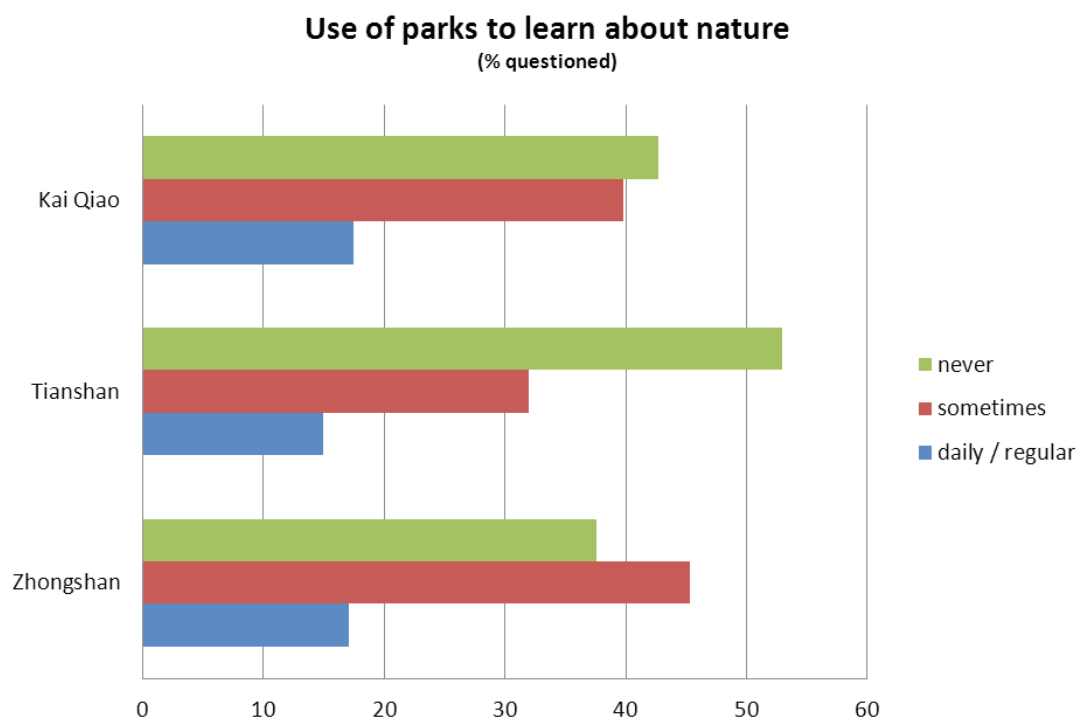

Fig. 3. Visit of the parks to observe nature (in \% questioned persons).

Use of parks to learn about nature

(\% questioned)

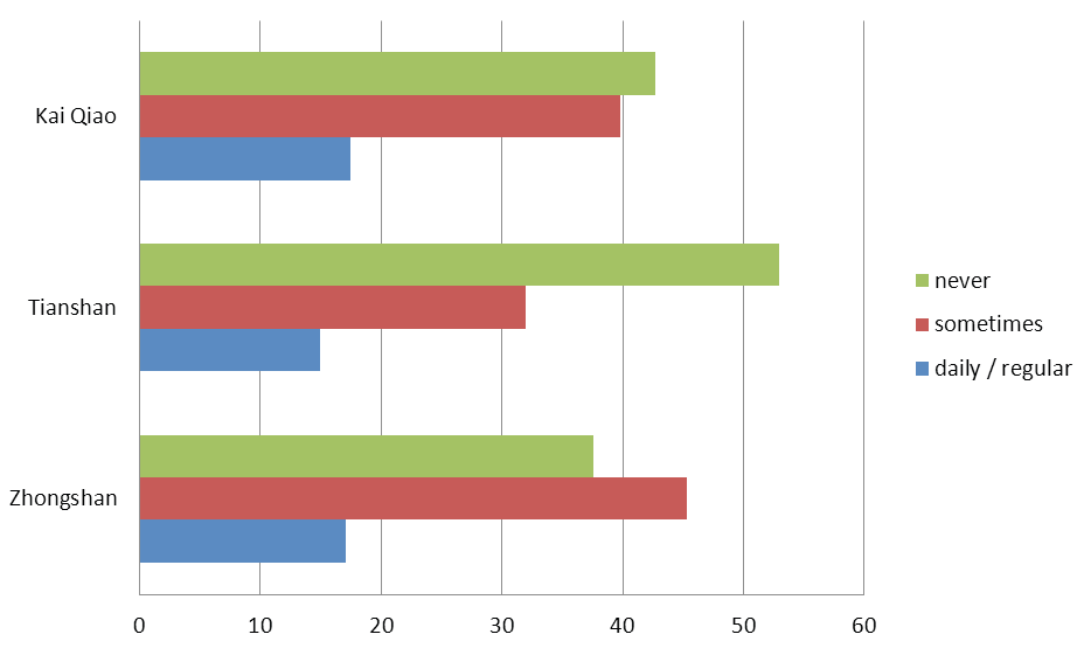

Fig. 4. Learning about nature while visiting the parks (in \% questioned persons).

Many of the visitors express being regular observers of nature in the parks (36-44\%). A majority does this only sometimes and a certain percentage of the visitors never (11-18\%). This seems to be more an emotional relation than an educational one (Fig. 3). 
The majority of the visitors never use the parks to learn about nature (37-53\%). This shows the still unused potentials of these parks to built-up ecological knowledge starting from already existing emotional relations between people and the park (Fig. 4).

It becomes clear that nature experience is not only dependent on the offered nature of the parks but also on the nature-related pre-education of the visitors (Breuste et al., 2013a).

\section{Recreation - Buenos Aires, Argentina, study}

The majority of visitors are middle-class people (83-91\%). They visit the parks because of their natural features (38-58\%) and for recreation and stress relief (23-39\%) (Fig. 5). Age, sex and family situation influence the visits (time, frequency, duration, activities and preferences of the features). The utilization of the parks is more or less comparable in frequency, duration and activities.

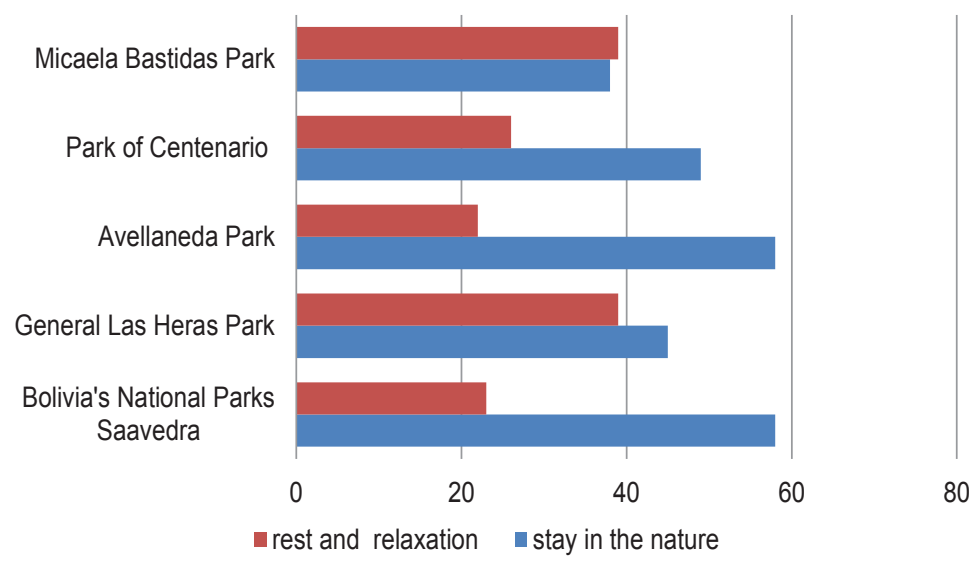

Fig. 5. Reasons for visiting the parks (\% questioned people).

The majority of visitors stay more than two hours in the parks (50-68\%). Younger (15-21 years old) and older people (more than 50 years old) stay longer than others (up to 68\% of these groups). The frequency of visits varies between parks and social groups. A large proportion of the users visit the park every day or whenever they have time (62-76\%), independent of social status but depending on age and family situation. A bigger group visits the parks every day (17-40\%). This shows the importance of these green spaces as providers of recreational functions in the daily life of people living next to the areas. Visits to green spaces are the most time consuming and most important free-time activity for 36-46\% of the people in the study. This open space activity is much more important than any other activity (followed by shopping, family visits, special sports and cinema visits). Cleanliness (35-59\%) and security (14-21\%) are very important for the visitors, more than natural elements (trees and plants, (6-15\%). The lawns and the trees are the most valued natural features (35-55\%). In 
combination, the trees provide shade, structure the space and give a picturesque impression. The lawns allow for resting, walking (partly) and observing.

The majority of visitors come from a distance of less than $500 \mathrm{~m}$ (37-57\%). This can vary if there are no green spaces nearer or if a green space further away is more attractive. This is the case with the Parque Micaela Bastidas where $45 \%$ of visitors travel a distance of more than $2 \mathrm{~km}$ to the park (Fig. 6). For more than $40 \%$ of the visitors, the distance is always the main reason to visit the most frequently used park. This means that the parks are mainly important for the neighbourhood population and should fit their recreational interests.

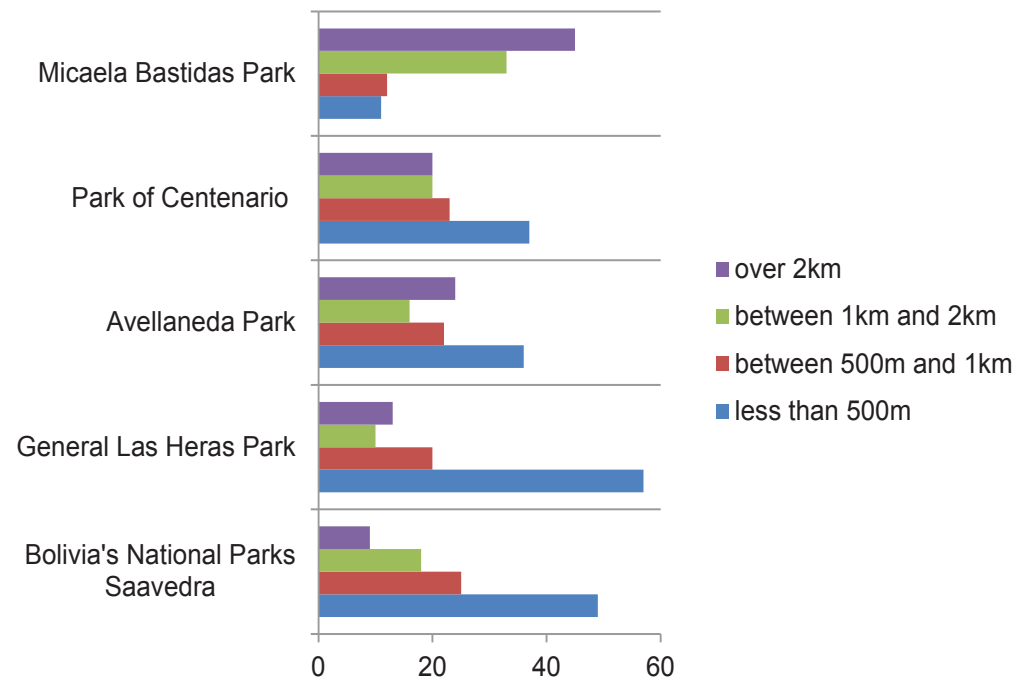

Fig. 6. Distance from where the visitors came to the parks in Buenos Aires (\% questioned people).

The visitors involve mostly in activities such as sitting, resting on lawns, sunning oneself, reading, walking, walking dogs etc. Some activities such as sports, children's play or special activities like visits with children are more active. The activities can be partly in concurrence to each other depending on the size of the green space and the number of visitors doing them simultaneously. The spatial separation of functional activities helps to reduce conflicts. Overcrowding-based destruction of services can be avoided by a green planning strategy including the urban regional demand for recreation (Fig. 7) (Breuste et al., 2013a).

\section{Discussion}

Development of an evaluation tool for urban ecosystem services on site level (ESIS - Ecosystem Service Indication System)

There is a need for an evaluation tool for urban ecosystem services to compare studies and different parks on a qualified basis. Niemann (1982) developed a system of structural units of 

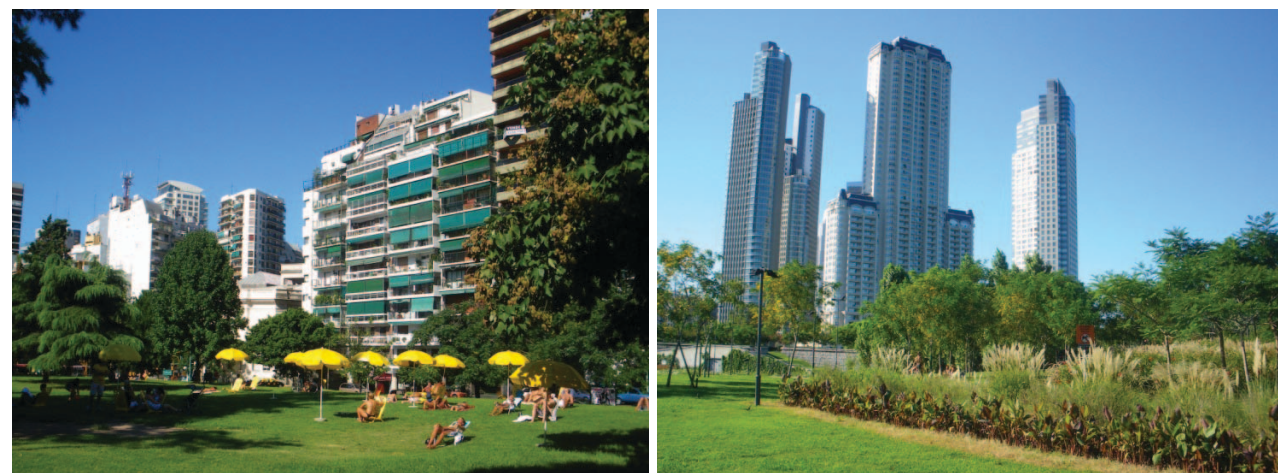

Fig. 7. Parks in Buenos Aires - Parque General Las Heras and Parque Micaela Bastidas (Photos: J. Breuste).

different levels (landscape elements and landscape units) which were used to define quantitative functional degrees. Breuste (2009) implemented this system on a large scale for urban areas; Stern (2010) adopted it for urban parks in an example study in Shanghai.

The system allows the connection of ecosystem functions to spatial elements of the urban system or landscape and their quantification. It is developed for evaluation of green areas as spatial units providing ecosystem services. It allows the localization of ecosystem service qualities and the development of a spatial pattern of these qualities and quantities for a whole urban area. The comparison of the quality and quantity of defined ecosystem services between different green areas is possible (Stern, 2010).

The evaluation tool consists of (spatial) elements on two levels, which are carriers of the ecosystem service functions and can be exactly localized in urban areas. The different ecosystem services can be qualified by indicators and quantified by the dimension or quantity of the indicator. With this tool the quantity of an ecosystem function can be individually localized in the urban area and aggregated for green areas, for example (Fig. 8).

The system starts with two levels of spatial dimensions (level A and level B in Fig. 8). The first is the green patch level. These consists of the basic units providing direct ecosystem services, e.g. lawns, bush groups, single trees, small woods with different layers, flower beds etc. (Fig. 9).

For quantification of climate regulation service, e.g. the dimension of biomass, the extension of areas and their shape can be taken into account. Different species are habituated by different patch ecosystems and their availability in green areas can be indicators for this habitat function or biodiversity.

These patches are responsible for climate regulation, hydrological and biodiversity services. As elements of green areas (level B) they are responsible for more complex ecosystem services such as recreation, nature experience, health, cultural services etc. This second level of green area can be a reference level for the aggregated values of the patch-related ecosystem services.

The environment of the green areas influences the quantity of ecosystem services of the green area or in the case of large green areas, vice versa - the green areas influence the climate of the environment. These environmental relations are important. The climate regulation 


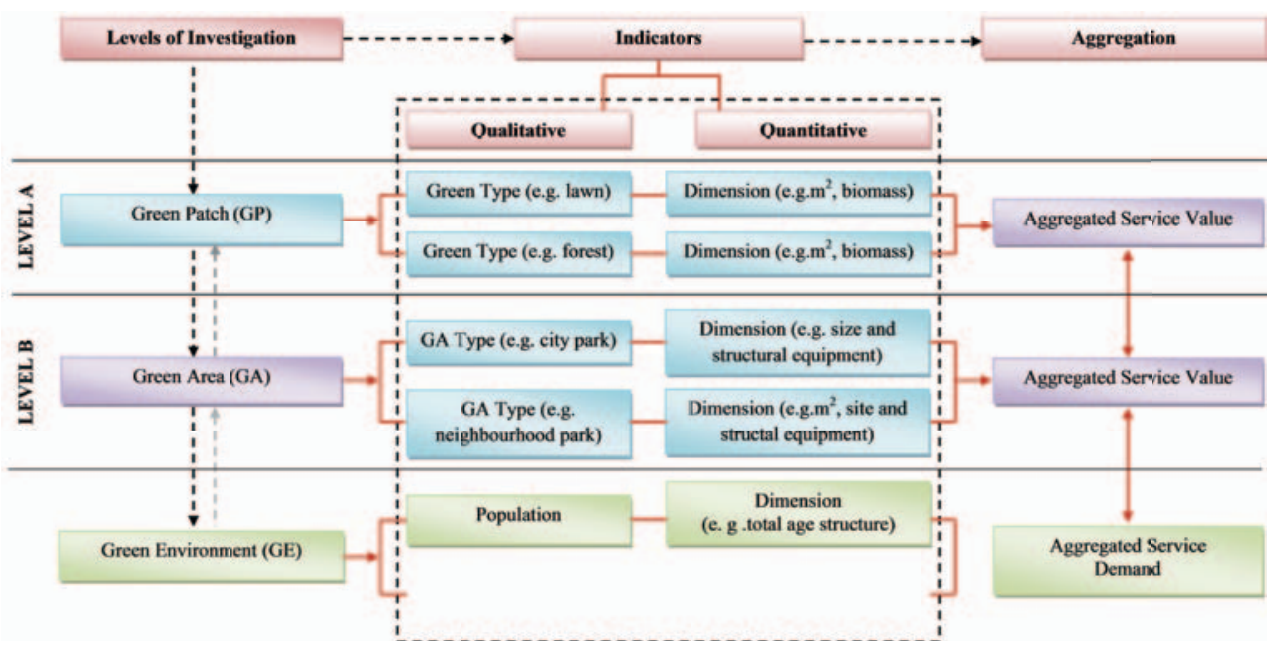

Fig. 8. Investigation levels for ecosystem services in ESIS tool.

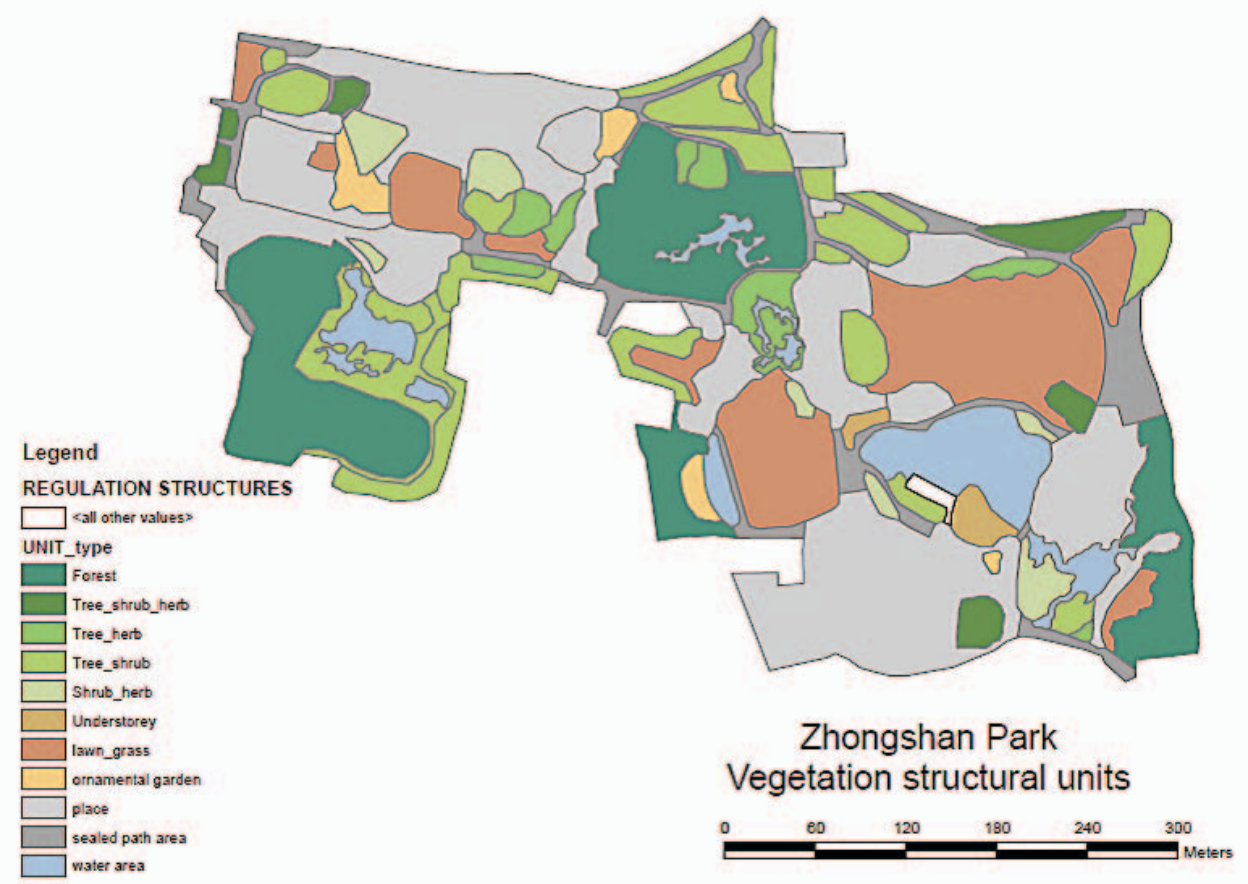

Fig. 9. Green patches as basis level for ecosystem services in Zhongshan Park, Shanghai (Stern, 2010). 
service of a green area starts to influence its built-up surrounding when the size of the green areas is big enough. On the other hand, the environment of green areas has a residential population which needs special ecosystem services, e.g. for recreation. These needs can also be quantified and compared with the quality and quantity of ecosystems services provided by the green areas located nearby. This comparison can help planners to overcome the possible gaps in ecosystem services in urban districts. This links to a planning process which investigates the ecosystems services systematically, rates and evaluates those using indicators and implements this knowledge in ecological planning.

\section{Conclusion}

Urban green in different countries and cities can be different. Many studies reflect valuable results on urban green but have not investigated comparable types of green. A glance at recently published literature reinforces the evidence of climate change effects at all scales. Cities will be among the most affected ecosystems that are also first influenced by climate changes. A review of numerous observed and predicted climatic extremes has been reported by Easterling et al. (2000). Increased precipitation and runoff in some regions will lead to an increased frequency and/or intensity of flooding with consequent economic costs. To cope with these challenges, an ecosystem services approach has the potential for adapting cites to climate change at all spatial scales. The cooling effect of urban green (e.g. Gill et al., 2007) can be a key concern for thermal comfort and for combating the microclimatic changes (including heat island effects) besides helping to plan settlements in a sustainable way. The climate regulation service will become more important in most of the cities worldwide. Green areas will be the most effective providers of moderate climate in heat stress situations without any energy consumption. This climate regulation function will be necessary in all areas of cities where people live and will link to a changed design of new urban residential areas and to a necessary change and adaption of existing residential areas. To adapt cities to climate change challenges means to improve ecosystem services provided mostly by urban green (Gill et al., 2007).

Urban biodiversity and urban nature experience will become more and more important in urban development. Cities offer habitats which only rarely exist in the intensively used cultural landscapes of the surrounding areas. They become alternatives for native flora and fauna but also offer perspectives for new forms of nature as urban-industrial nature. Nature protection in many countries has changed its perspective from the isolated protection of rare species and habitats to protect nature to support nature experience. This has even become the most important reason for protecting urban nature. In many countries the third generation is already growing up without any close relationship to nature or experiencing nature. The opportunities that urban nature offers for nature experience, learning from nature or even simply to enjoy nature are still only partly recognized. These services have to become a part of new urban planning concepts.

The growing cities need publically accessible open spaces for recreation. This can be supported by public urban green spaces like parks. Other forms of nature can also provide this 
service (forests, wetlands, agricultural land, wasteland etc.). The actual studies show that traditional public parks still play an import role in recreation in urban neighbourhoods. They are needed here, directly next to the people in order to fulfil the urgent needs of urban dwellers for recreation as part of their daily lives. The studies show that ecosystem services are needed in cities of very different economic and cultural background. In every city, especially in fast developing cities of the developing world, where this service does not develop parallel to urban growth, it has to be included in urban planning.

Rapid urban growth links to more intensive use of all urban space and to a territorial extension of cities (Smith, 2002). All available urban space is actually used for economic profitable land use (residential and commercial buildings etc.). Only social groups with high income can afford to have their own green open space (Qureshi et al., 2010a). For the majority of urban dwellers only public green remains as a provider of adequate regulated climate, urban outdoor recreation and nature experiences. Nevertheless, due to reduced finances and less public income, communities are economically unable to provide functional public green spaces that are equally distributed in all residential areas. Green areas outside the cities cannot replace the necessary green areas inside the cities, which are disappearing apace or cannot be added or linked to the existing ones.

The trend suggests that the majority of urban dwellers will have limited access to urban ecosystem services in their neighbourhoods. This will influence their health status (Martens, 1999) and contact with nature. The need for ecosystem services in residential areas is increasing, whereas the ability to provide these services by communities is decreasing. A cautious inventory of existing ecosystem services at the site level for each green area is therefore recommended. The identification of ecosystem service gaps in the urban form is advisable to develop them with the remaining communal abilities exactly at the places where a specific service or services are urgently needed.

Urban ecosystem service should become part of urban planning concepts. This includes the definition of targets for urban ecosystem services in an urban regional context and in a proposed quantity. This is actually only partly the case, is often fragmented and especially not seen in a demand and supply context.

Urban green is not always the same in different countries and cities. Many studies reflect valuable results on urban green but have not investigated the same kind of areas. To avoid incomparability between different studies, this paper reports only on public urban green spaces, for instance different kinds of public parks, without single specialized functions such as for sports.

\section{References}

Ahern, J. (2007). Green infrastructure for cities: the spatial dimension. In V. Novotny \& P. Brown (Eds.), Cities of the future: towards integrated sustainable water and landscape management (pp. 267-283). London: IWA Publishing.

Bolund, P. \& Hunhammar S. (1999). Ecosystem services in urban areas. Ecological Economics, 29(2), 293-301.

Breuste, J., Qureshi, S. \& Li J. (2013a). Scaling down the ecosystem services at local level for urban parks of three megacities. Hercynia, 46, 1-20.

Breuste, J. ,Schnellinger, J., Qureshi, S. \& Faggi A. (2013b). Investigations on habitat provision and recreation as ecosystem services in urban parks - two case studies in Linz and Buenos Aires. Darmstadt (= Conturec 5, Competence Network Urban Ecology), pp. 7-22.

Breuste, J., Feldmann H. \& Uhlmann O. (Eds.) (1998). Urban ecology. Berlin, Heidelberg: Springer. DOI: 10.1007/978-3-642-88583-9. 
Costanza, R. \& Folke C. (1997). Valuing ecosystem services with efficiency, fairness, and sustainability goals. In G.E. Daily (Ed.), Nature's Services - Societal Dependence on Natural Ecosystems (pp. 49-65). Washington: Island Press.

Czermak, P. (2008). Ecological assessment of parks in the city of Linz on the basis of the data set of breeding bird mapping (in German). Unpublished master's thesis, University Salzburg.

Easterling, D.R., Meehl, G.A., Parmesan, C., Changnon, S.A., Karl, T.R. \& Mearns L.O. (2000). Climate extremes: observations, modeling, and impacts. Science, 289, 2068-2074. DOI: 10.1126/science.289.5487.2068.

Gill, S.E., Handley, J.F., Ennos, A.R. \& Pauleit S. (2007). Adapting cities to climate change: the role of the green infrastructure. Built Environment, 33(1), 115-133.

Grimm, N.B., Foster, D., Groffman, P., Grove, J.M., Hopkinson, C.S., Nadelhoffer, K., Peters, D. \& Pataki D.E. (2008). The changing landscape: ecosystem responses to urbanisation and pollution across climatic and societal gradients. Frontiers in Ecology and the Environment, 6, 264-272. DOI: 10.1890/070147.

Kowarik, I. (1992). Das Besondere der städtischen Flora und Vegetation. In Natur in der Stadt - der Beitrag der Landespflege zur Stadtentwicklung. Schriftenreihe des Deutschen Rates für Landespflege, 61, 33-47.

Loram, A., Tratalos, J., Warren, P.H. \& Gaston K.J. (2007). Urban domestic gardens (X): the extent and structure of the resource in five major cities. Landsc. Ecol., 22, 601-615. DOI: 10.1007/s10980-006-9051-9.

Martens, P. (1999). How will climate change affect human health? Am. Sci.. 87, 534-541. DOI: 10.1511/1999.6.534.

Millennium Ecosystem Assessment (MEA) (2003). Ecosystems and Human Well-Being, a Framework for Assessment. Washington: Island Press.

Millennium Ecosystem Assessment (MEA) (2005). Ecosystems and Human Well-Being, Synthesis. London: Island Press.

Niemann, E. (1982). Methodology for determining the suitability, performance and capacity of landscape elements and landscape units (in German). Scientific disclosures by the Institute for Geography and Geoecology. Academy of Science of the GDR, Special Issue 2.

Nowak, D.J., Rowntree, R.A., McPherson, E.G., Sisinni, S.M., Kerkmann, E.R. \& Stevens J.C. (1996). Measuring and analyzing urban tree cover. Landsc. Urban Plann., 36, 49-57.

Pauleit, S., Duhme, F., 2000. Assessing the environmental performance of land cover types for urban planning. Landsc. Urban Plann., 52(1), 1-20.

Pauleit, S. \& Breuste J. (2011). Land use and surface cover as urban ecological indicators. In J. Niemelä, J. Breuste, T. Elmqvist, G. Guntenspergen, P. James \& N. McIntryre (Eds.), Urban ecology, patterns, processes, and applications (pp. 19-30). Oxford: Oxford University Press.

Qureshi, S. (2010). The fast growing megacity Karachi as a frontier of environmental challenges: Urbanization and contemporary urbanism issues. Journal of Geography and Regional Planning, 3, 306-321. http://www.academicjournals.org/JGRP

Qureshi, S. \& Breuste J.H. (2010). Prospects of biodiversity in the mega city Karachi, Pakistan: Potentials, constraints and implications. In N. Müller, P. Werner \& J. Kelcey (Eds.), Urban biodiversity and design - implementing the convention on biological diversity in towns and cities (pp. 497-517). Oxford: Wiley-Blackwell.

Qureshi, S., Breuste, J.H. \& Lindley S.J. (2010a). Green space functionality along an urban gradient in Karachi, Pakistan: A socio-ecological study. Hum. Ecol., 38, 283-294. DOI: 10.1007/s10745-010-9303-9.

Qureshi, S., Kazmi, S.J.H. \& Breuste J.H. (2010b). Ecological disturbances due to high cutback in the green infrastructure of Karachi: Analyses of public perception about associated health problems. Urban Forestry and Urban Greening, 9, 187-198. DOI: 10.1016/j.ufug.2009.08.003.

Santos L.D. \& Martins I. (2007). Monitoring urban quality of life: The Porto Experience. Social Indicators Research, 80, 411-425. DOI: 10.1007/s11205-006-0002-2.

Smith, N. (2002). New globalism, new urbanism: gentrification as global urban strategy. Antipode, 34, 427-450. DOI: $10.1111 / 1467-8330.00249$.

Stern, N. (2010). Assessment of the socio-ecological functions of green areas shown on the example of the mega city of Shanghai (in German). Unpublished doctoral disseration, University Salzburg.

Tratalos, J., Fuller, R.A., Warren, P.H., Davies, R.G. \& Gaston K.J (2007). Urban form, biodiversity potential and ecosystem services. Landsc. Urban Plann., 83(4), 308-317. DOI: 10.1016/j.landurbplan.2007.05.003.

Weissmair, W., Rubenser, H., Brander M. \& Schauberger R. (2000-2001). Breeding bird atlas of Linz (in German). Naturkundliches Jahrbuch der Stadt Linz, p. 46-47. 